\title{
The effects of Allium hookeri on the physicochemical characteristics and storage of pork sausage
}

\author{
Joo Hyung Lee, Seong Hee Choi* \\ Department of Food Science, Sun Moon University, Asan 31460, Korea
}

\section{삼채 첨가에 의한 돈육 소시지의 물리화학적 특성과 저장성에 미치는 영향}

\author{
이주형·최성희* \\ 선문대학교 식품과학과
}

\begin{abstract}
The effects of Allium hookeri (AH) on the physicochemical properties and storage of pork sausage were examined. Sausages were prepared with different levels of $\mathrm{AH}(0.5$ and $1 \%)$ and sodium nitrite $(50,100$, and $150 \mathrm{ppm})$, and stored at $4^{\circ} \mathrm{C}$ for four weeks. The addition of $\mathrm{AH}$ had little effect on the CIE color or texture value of the sausage. More than half of the added nitrite was removed during sausage preparation, and a further large reduction was observed during one week of storage. The TBARS content was observed to increase with storage, but lower increases were observed when more nitrite and AH were added. When stored for two or four weeks, the group with $100 \mathrm{ppm}$ nitrite and $1 \%$ AH showed lower TBARS values than the group with only $150 \mathrm{ppm}$ nitrite. The total microbial count after storage for four weeks was lower in sausage with $50 \mathrm{ppm}$ nitrite and $1 \% \mathrm{AH}$ than in sausage with only $100 \mathrm{ppm}$ nitrite, and the sausage with $100 \mathrm{ppm}$ nitrite and $1 \% \mathrm{AH}$ exhibited the same microbial count as that with only $150 \mathrm{ppm}$ nitrite. These results suggest that $\mathrm{AH}$ is a potential substitute for nitrite for use in sausage production by suppressing TBARS increases and inhibiting microbial growth during storage.
\end{abstract}

Key words : Allium hookeri, sausage, nitrite, TBARS

\section{서 론}

경제발전과 함께 우리 식생활의 큰 변화 중 하나는 육류 와 육가공품의 소비량이 증가한 것이며, 특히 돈육을 이용 한 소시지의 소비량이 높다(1). 한국육가공협회에 따르면 2018년 국내 소시지 생산량은 77,158톤으로 전체 육가공품 생산량 214,871 톤의 $35.9 \%$ 를 차지하며, 이는 2008 년의 50,267 톤에 비해 $53.5 \%$ 증가한 양이다(www.kmia.or.kr) 아질산염은 염지 육가공품의 필수적인 첨가제로서 발색, 풍미 증진, Clostridium botulimum 등의 식중독균과 부패 미생물 성장 억제, 지방산화 억제와 같이 매우 다양한 기능

*Corresponding author. E-mail : choish@sunmoon.ac.kr Phone : 82-41-530-2281, Fax : 82-41-530-2917

Received 25 June 2019; Revised 15 July 2019; Accepted 22 July 2019.

Copyright (c) The Korean Society of Food Preservation. All rights reserved.
이 있다(2,3). 그러나 과다 섭취할 경우 n-nitrosamine과 같은 발암 물질을 생성하고, metmyogolbin을 생성하여 청색증을 유발할 수 있어 사람의 건강에 좋지 않은 영향을 미칠 수 있다(4,5). 아질산염의 이러한 부작용 가능성은 소비자들로 하여금 육가공품에 대한 부정적인 인식을 갖게 하므로 인간 의 건강에 무해하면서 항균 및 항산화성이 우수한 천연물로 의 대체가 요구되고 있다(6). 최근 a-tocopherol, $\beta$-carotene, L-ascorbic acid와 같은 천연 항산화 영양소와 함께 녹차 등에 다량 함유 되어 있는 폴리페놀 성분은 강한 항산화 기능을 가져 유해 산소로부터 인체를 보호해 주는 역할을 한다고 보고되면서 식용식물의 천연 항산화 기능에 관한 연구가 활발하다 $(7,8)$.

삼채(Allium hookeri)는 파속(屬) 식물로 히말라야 산맥 해발 1,400-4,200미터의 고원지대에서 자생하며, 중국, 인 도, 부탄, 스리랑카, 미얀마 등지에 분포한다(9-11). 약 3,000 년 전부터 식용과 약용으로 사용해 왔으며 뿌리, 잎, 순 모두 식용 가능하고, 식이 유황화합물이 마늘보다 6배 많다 
고 알려져 있다. 또한 삼채는 단백질, 당, 섬유소, ascorbic acid, phytosterol, total phenol 등이 함유되어 있어 양파와 마늘을 대체하는 양념채소로도 널리 사용된다(12-14). 유황 화합물을 많이 함유하는 파, 마늘, 양파 등 Allium 속 식물과 함께 삼채는 항산화, 항암, 항염, 항균, 알코올성 간독성 완화, 체지방 축적 억제, 항고지혈증 및 혈당 강하 작용 등 다양한 생리활성이 연구되었다(15-26).

이러한 삼채는 최근 국내에서도 재배되어, 그 성분과 건 강기능에 대한 관심이 높아지고 다양한 활용기술이 연구되 고 있다(29-31). 하지만 아직 국내산 삼채의 육가공품에 활 용에 대한 연구는 활발히 이루어지고 있지 않은 실정이다. 따라서 본 연구에서는 삼채의 기능성을 고부가가치 육가공 품 개발에 활용하기 위한 기초 자료를 얻기 위하여 이의 첨가가 돈육 소시지의 물리 화학적 특성과 저장성에 미치는 영향을 살펴보았다.

\section{재료 및 방법}

\section{돈육 소시지의 제조}

돈육 소시지는 냉장 전지육(도드람 한돈)을 $5 \mathrm{~mm}$ 쵸파로 2 회 갈아서 분쇄 전지육을 준비하여 고기 $750 \mathrm{~g}$ 에 소금, 설탕, 복합인산염(Inphos plus \#3924, Woosung Meatpro Co., Ltd, Seoul, Korea) 등 재료를 첨가하여 Table 1 의 조성에 따라 8 개 군으로 제조하였다. 아질산염은 $0,50,100,150$ $\mathrm{ppm}$ 을 첨가하였고, $50 \mathrm{ppm}, 100 \mathrm{ppm}$ 군에는 삼채분말을 각각 $0,0.5,1 \%$ 첨가하였다. $1 \mathrm{~kg}$ 씩 계량된 배치들은 믹서로 균일하게 혼합하고, STX Turboforce 3000 Electric Meat Grinder (STX International, Lincoln, NE, USA)에 불린 천연 돈장 casing을 끼워 충진하여 소시지 링크를 뽑았다. 소시지 링크는 지퍼 백에 넣어 하룻밤 냉장 보관 후 다음날 가열 처리하였다. 가열방법은 소시지 중심온도가 $75^{\circ} \mathrm{C}$ 도달 후 20 분간 온도를 유지하고, 얼음물로 냉각 후에 $4^{\circ} \mathrm{C}$ 냉장고에 저장하면서 분석 시료로 사용하였다.

\section{일반성분 분석}

일반성분은 $\mathrm{AOAC}(32)$ 방법에 의하여 수분(oven-dry 법), 조지방(Soxhlet 법), 조단백(microkjeldahl 법) 및 조회분을
측정하였다. 분석은 각 시험군별 3 처리반복 시료를 분석시 료로 하여 각 시료는 2 반복 분석하였다.

\section{색도 측정}

육색은 색차계(Chromameter CR-300, Minolta Corporation, Ramsey, NJ, USA)를 이용하여 CIE(Commission Internationale de $l^{\prime}$ Eclairage) $L^{*}$ (lightness), $a^{*}$ (red-green) 및 $b^{*}$ (yellow-blue) 값을 측정하였으며, 표준 색도판은 Minolta calibration plate No. 20033044로서 $Y=92.7, x=0.3136, y=0.3195$ 를 사용하 였다.

\section{조직감 측정}

조직감은 시료를 일정한 크기로 자른 후 Texture analyzer(Sun Scientific Co, Model CR-500DX, Tokyo, Japan) 에 직경 $20 \mathrm{~mm}$ plunger를 장착하여 2회 반복 시료를 가압하 였을 때 얻어지는 force-time curve로부터 경도(hardness), 응집성(cohesiveness), 씹힘성(chewiness)을 측정하였다. 측 정조건은 시료 높이 $15 \mathrm{~mm}$, crosshead 속도 $0.5 \mathrm{~mm} / \mathrm{sec}$, 침투율 $75 \%$ 로 하였다.

\section{아질산 이온 측정}

시료의 아질산 이온 함량은 sulfanilic acid와 $a$ -naphthylamine- $\mathrm{HCl}$ 을 함유하는 Griess reagent와 반응시켜 nitrite의 diazo-coupling을 $540 \mathrm{~nm}$ 에서 비색정량 하였다. 시 료용액과 함께 표준용액(0.1-1 ppm)에 대한 흡광도를 측정 한 후 표준곡선를 작성하여 nitrite 함량(ppm)을 계산하였다. 시료는 소시지 $1 \mathrm{~g}$ 을 증류수 $40 \mathrm{~mL}$ 에 균질하여 $80^{\circ} \mathrm{C}$ 항온수 조에서 2시간 가열한 다음 포화 $\mathrm{HgCl}_{2}$ 용액 $5 \mathrm{~mL}$ 를 가하여 냉각한 후 $50 \mathrm{~mL}$ 로 부피를 조정한 다음 whatman No. 1 filter paper로 여과하였으며, 시료의 아질산 이온 함량이 $20 \mathrm{ppm}$ 이 넘는 경우에는 시료용액을 2-3배 희석하여 분석 하였다.

\section{TBARS 함량 측정}

육가공품의 저장 중 지방 산패 정도를 평가하기 위하여 thiobarbituric acid reactive substances(TBARS) 함량을 Witte 등(33)의 방법에 의하여 측정하였다. 시료 $5 \mathrm{~g}$ 에 $20 \%$ trichloroacetic acid in $2 \mathrm{M}$ phosphoric acid 용액 $25 \mathrm{~mL}$ 을

Table 1. Recipe for pork sausages added with $A$ hookeri

\begin{tabular}{|c|c|c|c|c|c|c|c|c|}
\hline Ingredients (g) & $\mathrm{N} 0+\mathrm{A} 0^{1)}$ & $\mathrm{N} 50+\mathrm{A} 0$ & $\mathrm{~N} 50+\mathrm{A} 0.5$ & $\mathrm{~N} 50+\mathrm{A} 1.0$ & $\mathrm{~N} 100+\mathrm{A} 0$ & $\mathrm{~N} 100+\mathrm{A} 0.5$ & $\mathrm{~N} 100+\mathrm{A} 1.0$ & $\mathrm{~N} 150+\mathrm{A} 0$ \\
\hline Pork & 750 & 750 & 750 & 750 & 750 & 750 & 750 & 750 \\
\hline Salt & 14 & 14 & 14 & 14 & 14 & 14 & 14 & 14 \\
\hline Sugar & 10 & 10 & 10 & 10 & 10 & 10 & 10 & 10 \\
\hline Phosphate & 2 & 2 & 2 & 2 & 2 & 2 & 2 & 2 \\
\hline Water & 224 & 224 & 219 & 214 & 224 & 219 & 214 & 224 \\
\hline Nitrite(mg) & 0 & 50 & 50 & 50 & 100 & 100 & 100 & 150 \\
\hline Allium hookeri & 0 & 0 & 5 & 10 & 0 & 5 & 10 & 0 \\
\hline
\end{tabular}

${ }^{11}$ Group abbreviations: $\mathrm{N}$ represents nitrite in ppm, and A represents Allium hookeri in \% added as an ingredient of sausages. 
첨가하여 $14,000 \mathrm{rpm}$ 으로 2 분간 균질화 한 다음 증류수를 사용하여 $50 \mathrm{~mL}$ 로 부피를 조정하여 Whatman No. 1 filter paper로 여과하였다. 여과액 $2 \mathrm{~mL}$ 를 취해 $5 \mathrm{mM} \mathrm{TBA}$ 용액 $2 \mathrm{~mL}$ 를 혼합하여 $95^{\circ} \mathrm{C}$ 에서 1 시간 가열한 후 냉각하여 530 $\mathrm{nm}$ 흡광도를 측정하여 TBARS 농도를 계산하였다.

\section{일반세균 측정}

$4^{\circ} \mathrm{C}$ 에서 1 주와 4 주 저장한 소시지의 일반세균수를 표준 평판법을 이용하여 측정하였다. 시료 $2 \mathrm{~g}$ 을 멸균수 $18 \mathrm{~mL}$ 에 균질화하고 단계 희석하였다. 희석 시료 $0.5 \mathrm{~mL}$ 를 petri dish에 취하여 $45^{\circ} \mathrm{C}$ 항온수조에서 굳지 않도록 유지한 $2.35 \%$ plate count agar(PCA) 배지를 $15 \mathrm{~mL}$ 씩 분주하여 잘 섞은 다음 수평으로 굳히고 $37^{\circ} \mathrm{C}$ 에서 24 시간 배양 후 군락 수를 측정하여 colony forming unit(CFU)/g을 계산하였다.

\section{통계처리}

실험결과는 SPSS program을 이용하여 ANOVA 분석 후, 각 실험군 간의 유의성을 $\mathrm{p}<0.05$ 수준에서 Duncan's multiple range test를 통하여 검정하였으며, 저장 1 주와 4 주 의 일반세균수의 저장기간에 대한 유의성은 Student $t$-test를 통하여 검정하였다.

\section{결과 및 고찰}

\section{일반성분}

아질산염 $0,50,100$ 및 $150 \mathrm{ppm}$ 과 삼채 분말 $0,0.5$ 및 $1 \%$ 를 첨가하여 제조한 8 종류 돈육 소시지의 일반성분을 분석한 결과는 Table 2 와 같다. 돈육 소시지의 조단백과 조지방 함량은 군 간에 유의한 차이가 없었다. 수분과 조회

Table 2. Proximate compositions of pork sausages prepared by addition of nitrite and $A$ hookeri

\begin{tabular}{ccccc}
\hline & \multicolumn{4}{c}{ Proximate compositions (\%) } \\
\cline { 2 - 5 } & Moisture & Crude protein & Crude fat & Crude ash \\
\hline $\mathrm{N} 0+\mathrm{A} 0^{2)}$ & $70.71 \pm 0.16^{\mathrm{abc}}$ & $18.54 \pm 0.73^{\text {ns }}$ & $10.52 \pm 0.35$ & $1.80 \pm 0.03^{\mathrm{a}}$ \\
$\mathrm{N} 50+\mathrm{A} 0$ & $70.19 \pm 0.35^{\mathrm{bc}}$ & $18.64 \pm 0.98$ & $9.58 \pm 0.84$ & $1.82 \pm 0.02^{\mathrm{a}}$ \\
$\mathrm{N} 50+\mathrm{A} 0.5$ & $71.60 \pm 0.14^{\mathrm{a}}$ & $17.12 \pm 1.50$ & $9.58 \pm 0.25$ & $1.76 \pm 0.07^{\mathrm{ab}}$ \\
$\mathrm{N} 50+\mathrm{A} 1.0$ & $71.85 \pm 0.63^{\mathrm{a}}$ & $17.83 \pm 1.55$ & $9.51 \pm 0.23$ & $1.81 \pm 0.04^{\mathrm{a}}$ \\
$\mathrm{N} 100+\mathrm{A} 0$ & $70.80 \pm 0.18^{\mathrm{abc}}$ & $17.30 \pm 0.47$ & $10.12 \pm 0.29$ & $1.76 \pm 0.04^{\mathrm{a}}$ \\
$\mathrm{N} 100+\mathrm{A} 0.5$ & $69.82 \pm 1.60^{\mathrm{c}}$ & $17.76 \pm 1.41$ & $9.64 \pm 0.68$ & $1.67 \pm 0.02^{\mathrm{b}}$ \\
$\mathrm{N} 100+\mathrm{A} 1.0$ & $70.73 \pm 0.17^{\mathrm{abc}}$ & $17.01 \pm 0.87$ & $10.58 \pm 0.13$ & $1.76 \pm 0.02^{\mathrm{a}}$ \\
$\mathrm{N} 150+\mathrm{A} 0$ & $71.23 \pm 0.53^{\mathrm{ab}}$ & $18.14 \pm 1.64$ & $10.19 \pm 0.60$ & $1.60 \pm 0.05^{\mathrm{c}}$
\end{tabular}

${ }^{1)}$ Sausages prepared with addition of sodium nitrite $(0,50,100$, and $150 \mathrm{ppm})$ and $A$ hookeri powder $(0,0.5$, and $1.0 \%)$.

${ }^{2)}$ Group abbreviations: $\mathrm{N}$ represents nitrites in ppm, and $A$ represents $\mathrm{A}$. hookeri in $\%$ added in the process of preparation of sausages.

${ }^{\mathrm{ac}} \mathrm{M}$ Means sharing a common supersctipt letter(s) in the same column are not significantly different $(p>0.05)$
분은 통계적으로 군 간에 유의한 차이가 있었으나, 첨가된 아질산염과 삼채 분말 양에 따른 뚜렷한 변화 양상은 발견 할 수 없었으며 실제 값에 있어서도 수분은 최저 $69.82 \%$, 최고 $71.85 \%$, 조회분은 최저 $1.60 \%$, 최고 $1.82 \%$ 로 그 차이 가 크지 않았다.

조직감

아질산염과 삼채 분말을 첨가하여 제조한 돈육 소시지의 조직감을 측정한 결과는 Table 3 과 같다. 응집성 (cohesiveness)은 군 간에 유의적인 차이가 발견되지 않았으 며, 경도(hardness)와 씹힘성(chewiness)은 군 간에 유의적 차이가 있었으나, 아질산염과 삼채의 첨가에 따른 뚜렷한 경향은 발견되지 않았다.

Table 3. Texture of pork sausages prepared by addition of nitrite and $A$ hookeri ${ }^{1}$

\begin{tabular}{cccc}
\hline & Hardness (g) & Cohesiveness $(\%)$ & Chewiness (g) \\
\hline $\mathrm{N} 0+\mathrm{A} 0^{2)}$ & $1,145 \pm 164^{\mathrm{b}}$ & $95 \pm 1.4^{\mathrm{ns}}$ & $1,086 \pm 157^{\mathrm{cd}}$ \\
$\mathrm{N} 50+\mathrm{A} 0$ & $1,478 \pm 136^{\mathrm{a}}$ & $99 \pm 5.7$ & $1,457 \pm 91^{\mathrm{a}}$ \\
$\mathrm{N} 50+\mathrm{A} 0.5$ & $1,338 \pm 87^{\mathrm{a}}$ & $95 \pm 9.3$ & $1,278 \pm 163^{\mathrm{abc}}$ \\
$\mathrm{N} 50+\mathrm{A} 1.0$ & $1,325 \pm 75^{\mathrm{a}}$ & $101 \pm 7.3$ & $1,343 \pm 155^{\mathrm{a}}$ \\
$\mathrm{N} 100+\mathrm{A} 0$ & $1,358 \pm 101^{\mathrm{a}}$ & $103 \pm 9.6$ & $1,393 \pm 125^{\mathrm{a}}$ \\
$\mathrm{N} 100+\mathrm{A} 0.5$ & $1,025 \pm 79^{\mathrm{b}}$ & $103 \pm 3.6$ & $1,057 \pm 75^{\mathrm{d}}$ \\
$\mathrm{N} 100+\mathrm{A} 1.0$ & $1,335 \pm 95^{\mathrm{a}}$ & $98 \pm 8.7$ & $1,309 \pm 134^{\mathrm{ab}}$ \\
$\mathrm{N} 150+\mathrm{A} 0$ & $1,118 \pm 61^{\mathrm{b}}$ & $100 \pm 6.8$ & $1,125 \pm 131 \mathrm{~b}^{\mathrm{cd}}$ \\
\hline
\end{tabular}

${ }^{11}$ Sausages prepared with addition of sodium nitrite $(0,50,100$, and $150 \mathrm{ppm})$ and $A$ hookeri powder $(0,0.5$, and $1.0 \%)$ were stored at $4^{\circ} \mathrm{C}$ for 4 weeks and the textural profiles were measured on a texture analyzer.

${ }^{2)}$ Group abbreviations: $\mathrm{N}$ represents nitrites in ppm, and A represents $A$ hookeri in $\%$ added in the process of preparation of sausages.

${ }^{\text {add }}$ Means sharing a common superscript letter(s) in the same column are not significantly different ( $>00.05)$.

${ }^{\mathrm{n}}$ Not significant.

\section{색 도}

육가공품의 색깔은 소비자의 제품 선택 시 기준이 되는 중요한 요소이다(34). 또한 식품의 색도 변화는 식품의 내적 외적 품질 변화를 보여주는 척도라 할 수 있다(35).

삼채 분말과 아질산염의 첨가량을 달리 하여 제조한 돈 육 소시지를 $4^{\circ} \mathrm{C}$ 에서 4 주 동안 저장하면서 색도를 측정한 결과 Table 4-6과 같다. $\mathrm{CIE} \mathrm{L}^{*}$ 값(lightness)은 아질산염 첨가에 의해 감소하여 아질산염이 첨가되지 않은 $\mathrm{NO}+\mathrm{A} 0$ 군 이 $65.93 \pm 0.52$ 로 가장 높은 값을 보였으며, 아질산염이 첨가 된 $\mathrm{N} 50+\mathrm{A} 0$ 군은 $62.18 \pm 0.88, \mathrm{~N} 100+\mathrm{A} 0$ 군은 $62.71 \pm 0.60$, $\mathrm{N} 150+\mathrm{A} 0$ 군은 $62.39 \pm 1.13$ 으로 아질산염이 첨가되지 않은 군에 비하여 낮았으나 아질산염 첨가군 사이에서는 큰 차이 를 보이지 않았다(Table 4). 한편 N100 첨가군에서는 삼채 첨가에 의해서는 $\mathrm{L}^{*}$ 값이 다소 감소하는 경향을 보였으며, 저장기간에 따라서는 모든 군에서 증가하는 경향을 보였 다. 
Table 4. CIE $\mathrm{L}^{*}$ values of pork sausages prepared by addition of nitrite and $A$ hookeri during storage at $4^{\circ} \mathrm{C}$ for 4 weeks ${ }^{1)}$

\begin{tabular}{ccccc}
\hline & 0 week & 1 week & 2 week & 4 week \\
\hline $\mathrm{N} 0+\mathrm{A} 0^{2)}$ & $65.93 \pm 0.52^{\mathrm{aB}}$ & $65.69 \pm 0.76^{\mathrm{aB}}$ & $66.35 \pm 0.82^{\mathrm{aB}}$ & $67.46 \pm 0.55^{\mathrm{aA}}$ \\
$\mathrm{N} 50+\mathrm{A} 0$ & $62.18 \pm 0.88^{\mathrm{bcdC}}$ & $64.43 \pm 1.14^{\mathrm{dB}}$ & $64.84 \pm 0.29^{\mathrm{cdAB}}$ & $65.54 \pm 0.55^{\mathrm{cA}}$ \\
$\mathrm{N} 50+\mathrm{A} 0.5$ & $62.61 \pm 0.60^{\mathrm{bcC}}$ & $65.25 \pm 0.71^{\mathrm{abcA}}$ & $63.77 \pm 0.49^{\mathrm{eB}}$ & $65.64 \pm 0.56^{\mathrm{cA}}$ \\
$\mathrm{N} 50+\mathrm{A} 1.0$ & $62.95 \pm 0.55^{\mathrm{bC}}$ & $64.80 \pm 0.75^{\mathrm{bcdAB}}$ & $64.54 \pm 0.85^{\mathrm{dB}}$ & $65.29 \pm 0.38^{\mathrm{cA}}$ \\
$\mathrm{N} 100+\mathrm{A} 0$ & $62.71 \pm 0.60^{\mathrm{bC}}$ & $65.52 \pm 0.63^{\mathrm{abB}}$ & $65.95 \pm 0.34^{\mathrm{abB}}$ & $67.25 \pm 0.43^{\mathrm{aA}}$ \\
$\mathrm{N} 100+\mathrm{A} 0.5$ & $61.76 \pm 1.03^{\mathrm{cdD}}$ & $64.70 \pm 0.70^{\mathrm{cdC}}$ & $65.50 \pm 0.55^{\mathrm{bBB}}$ & $66.28 \pm 0.59^{\mathrm{bA}}$ \\
$\mathrm{N} 100+\mathrm{A} 1.0$ & $61.42 \pm 1.32^{\mathrm{dC}}$ & $64.39 \pm 0.53^{\mathrm{dB}}$ & $65.11 \pm 1.29^{\mathrm{cdB}}$ & $66.68 \pm 0.35^{\mathrm{bA}}$ \\
$\mathrm{N} 150+\mathrm{A} 0$ & $62.39 \pm 1.13^{\mathrm{bcB}}$ & $65.33 \pm 0.55^{\mathrm{abcA}}$ & $65.01 \pm 0.78^{\mathrm{cdA}}$ & $65.66 \pm 0.71^{\mathrm{cA}}$ \\
\hline
\end{tabular}

${ }^{1)}$ Sausages prepared with addition of sodium nitrite $(0,50,100$, and $150 \mathrm{ppm})$ and $A$ hookeri powder $(0,0.5$, and $1.0 \%)$ were stored at $4{ }^{\circ} \mathrm{C}$ for 4 weeks and the $\mathrm{CIE} \mathrm{L}^{*}, \mathrm{a}^{*}$ and $\mathrm{b}^{*}$ values were measured on a chromameter.

${ }^{2)}$ Group abbreviations: $\mathrm{N}$ represents nitrites in ppm, and $\mathrm{A}$ represents $A$ hookeri in $\%$ added in the process of preparation of sausages.

${ }^{a-d}$ Means sharing a common superscript letter(s) in a column are not significantly different $(\mathrm{p}>0.05)$.

${ }^{A-D}$ Means sharing a common superscript letter(s) in a row are not significantly different $(\mathrm{p}>0.05)$.

Table 5는 적색도(redness)를 나타내는 CIE $\mathrm{a}^{*}$ 값으로 아 질산염 첨가에 의해 현저히 증가하여 아질산염이 첨가되지 않은 $\mathrm{N} 0+\mathrm{A} 0$ 군이 $3.48 \pm 0.48$ 로 가장 낮은 값을 보였으며, 아질산염이 $50-150 \mathrm{ppm}$ 첨가된 군들에서는 각각 $10.13 \pm 0.33,11.36 \pm 0.45,9.59 \pm 0.70$ 의 값을 보여 아질산염이 첨가되지 않은 군보다 현저히 높았으나 아질산염 첨가량에 따른 적색도의 차이는 뚜렷하지 않았다. 아질산염 첨가에 의한 적색도의 현저한 증가와 아질산염 $50 \mathrm{ppm}$ 이상에서 적색도가 더이상 크게 증가되지 않은 결과는 육색 고정을 위하여 아질산염 $50 \mathrm{ppm}$ 이면 충분한 수준이라고 보고한

Table 5. CIE a* values of pork sausages prepared by addition of nitrite and $A$ hookeri during storage at $4^{\circ} \mathrm{C}$ for 4 weeks $^{1)}$

\begin{tabular}{ccccc}
\hline & 0 week & 1 week & 2 week & 4 week \\
\hline $\mathrm{N} 0+\mathrm{A} 0^{2)}$ & $3.48 \pm 0.48^{\mathrm{fD}}$ & $4.27 \pm 0.71^{\mathrm{eC}}$ & $4.83 \pm 0.33^{\mathrm{AB}}$ & $5.94 \pm 0.23^{\mathrm{fA}}$ \\
$\mathrm{N} 50+\mathrm{A} 0$ & $10.13 \pm 0.33^{\mathrm{CB}}$ & $10.45 \pm 0.38^{\mathrm{bA}}$ & $10.46 \pm 0.19^{\mathrm{bA}}$ & $9.83 \pm 0.28^{\mathrm{BB}}$ \\
$\mathrm{N} 50+\mathrm{A} 0.5$ & $10.68 \pm 0.41^{\mathrm{bA}}$ & $10.02 \pm 0.42^{\mathrm{bcB}}$ & $10.88 \pm 0.23^{\mathrm{aA}}$ & $9.72 \pm 0.21^{\mathrm{bcB}}$ \\
$\mathrm{N} 50+\mathrm{A} 1.0$ & $8.42 \pm 0.34^{\mathrm{eC}}$ & $8.91 \pm 0.38^{\mathrm{AB}}$ & $9.36 \pm 0.13^{\mathrm{eA}}$ & $9.12 \pm 0.27^{\mathrm{dAB}}$ \\
$\mathrm{N} 100+\mathrm{A} 0$ & $11.36 \pm 0.45^{\mathrm{aA}}$ & $10.86 \pm 0.32^{\mathrm{aB}}$ & $10.28 \pm 0.25^{\mathrm{bC}}$ & $9.53 \pm 0.21^{\mathrm{CD}}$ \\
$\mathrm{N} 100+\mathrm{A} 0.5$ & $10.15 \pm 0.31^{\mathrm{CA}}$ & $9.73 \pm 0.27^{\mathrm{BB}}$ & $9.32 \pm 0.26^{\mathrm{D}}$ & $8.48 \pm 0.28^{\mathrm{eC}}$ \\
$\mathrm{N} 100+\mathrm{A} 1.0$ & $10.13 \pm 0.51^{\mathrm{CA}}$ & $10.07 \pm 0.25^{\mathrm{bcAB}}$ & $9.77 \pm 0.32^{\mathrm{dB}}$ & $8.64 \pm 0.21^{\mathrm{CC}}$ \\
$\mathrm{N} 150+\mathrm{A} 0$ & $9.59 \pm 0.70^{\mathrm{d}}$ & $10.04 \pm 0.43^{\mathrm{bc}}$ & $10.16 \pm 0.19^{\mathrm{C}}$ & $10.14 \pm 0.36^{\mathrm{a}}$ \\
\hline
\end{tabular}

${ }^{1)}$ Sausages prepared with addition of sodium nitrite $(0,50,100$, and $150 \mathrm{ppm})$ and $A$ hookeri powder $(0,0.5$, and $1.0 \%)$ were stored at $4{ }^{\circ} \mathrm{C}$ for 4 weeks and the CIE $L^{*}, a^{*}$ and $b^{*}$ values were measured on a chromameter.

${ }^{2)}$ Group abbreviations: $\mathrm{N}$ represents nitrites in ppm, and $\mathrm{A}$ represents $A$ hookeri in $\%$ added in the process of preparation of sausages.

${ }^{a+}$ Means sharing a common superscript letter(s) in a column are not significantly different $(\mathrm{p}>0.05)$

${ }^{A-D}$ Means sharing a common superscript letter(s) in a row are not significantly different $(\mathrm{p}>0.05)$.
Wesley 등(36)의 결과와 유사한 것이다.

적색도는 또한 삼채 첨가에 의해 영향을 받아 다소 감소 하는 경향을 보였으나 그 폭은 크지 않았다. 저장 기간에 따른 적색도의 변화는 처리군에 따라 차이가 있었다. 아질 산염이 첨가되지 않은 $\mathrm{N} 0+\mathrm{A} 0$ 군은 아질산염이 첨가된 나 머지 7군들에 비하여 매우 낮은 $\mathrm{a}^{*}$ 값을 보였으나 저장기간 이 길어질수록 차츰 높아지는 결과를 보였다. 아질산염 50 $\mathrm{ppm}$ 과 $100 \mathrm{ppm}$ 의 저아질산염 군에서는 저장에 따라 $\mathrm{a}^{*}$ 값이 낮아지는 경향이었으나 $150 \mathrm{ppm}$ 군에서는 저장기간 중 변화가 없었다.

황색도(yellowness)를 나타내는 CIE b* 값은 아질산염 첨가군이 무첨가군에 비해 낮은 값을 보였으나 첨가량에 따른 차이는 뚜렷하지 않았다(Table 6). 삼채 첨가는 황색도 를 다소 증가시키는 것으로 나타났다. 또한 저장에 따른 황색도의 변화를 보면 아질산염을 첨가하지 않은 소시지에 서는 저장기간이 길어짐에 따라 황색도가 다소 감소하는 경향이었으나, 아질산염과 삼채를 첨가한 군에서는 황색도 가 대체로 증가하는 경향이었다.

Table 6. CIE $b^{*}$ values of pork sausages prepared by addition of nitrite and $A$ hookeri during storage at $4^{\circ} \mathrm{C}$ for 4 weeks ${ }^{1)}$

\begin{tabular}{ccccc}
\hline & 0 week & 1 week & 2 week & 4 week \\
\hline $\mathrm{N} 0+\mathrm{A} 0^{2)}$ & $14.54 \pm 0.23^{\mathrm{aA}}$ & $14.74 \pm 0.41^{\mathrm{AA}}$ & $14.01 \pm 0.34^{\mathrm{aB}}$ & $14.07 \pm 0.22^{\mathrm{aB}}$ \\
$\mathrm{N} 50+\mathrm{A} 0$ & $12.39 \pm 0.11^{\mathrm{dC}}$ & $12.75 \pm 0.15^{\mathrm{BB}}$ & $12.78 \pm 0.24^{\mathrm{eB}}$ & $12.96 \pm 0.22^{\mathrm{eA}}$ \\
$\mathrm{N} 50+\mathrm{A} 0.5$ & $12.96 \pm 0.40^{\mathrm{CB}}$ & $13.49 \pm 0.14^{\mathrm{dAA}}$ & $12.84 \pm 0.17^{\mathrm{e}^{\mathrm{B}}}$ & $13.44 \pm 0.12^{\mathrm{dA}}$ \\
$\mathrm{N} 50+\mathrm{A} 1.0$ & $13.59 \pm 0.28^{\mathrm{bB}}$ & $13.92 \pm 0.21^{\mathrm{bA}}$ & $13.69 \pm 0.15^{\mathrm{bB}}$ & $13.66 \pm 0.22^{\mathrm{CB}}$ \\
$\mathrm{N} 100+\mathrm{A} 0$ & $12.64 \pm 0.19^{\mathrm{cdC}}$ & $13.32 \pm 0.21^{\mathrm{deA}}$ & $13.08 \pm 0.18^{\mathrm{dB}}$ & $13.27 \pm 0.16^{\mathrm{dA}}$ \\
$\mathrm{N} 100+\mathrm{A} 0.5$ & $12.92 \pm 0.64^{\mathrm{CC}}$ & $13.22 \pm 0.31^{\mathrm{eBC}}$ & $13.45 \pm 0.20^{\mathrm{cB}}$ & $13.88 \pm 0.17^{\mathrm{bA}}$ \\
$\mathrm{N} 100+\mathrm{A} 1.0$ & $13.40 \pm 0.27^{\mathrm{bB}}$ & $13.60 \pm 0.23^{\mathrm{CB}}$ & $13.46 \pm 0.29^{\mathrm{cB}}$ & $13.91 \pm 0.22^{\mathrm{abA}}$ \\
$\mathrm{N} 150+\mathrm{A} 0$ & $12.93 \pm 0.44^{\mathrm{c}}$ & $13.15 \pm 0.27^{\mathrm{e}}$ & $12.89 \pm 0.13^{\mathrm{d}}$ & $12.97 \pm 0.13^{\mathrm{e}}$ \\
\hline
\end{tabular}

${ }^{1)}$ Sausages prepared with addition of sodium nitrite $(0,50,100$, and $150 \mathrm{ppm})$ and $A$ hookeri powder $(0,0.5$, and $1.0 \%)$ were stored at $4^{\circ} \mathrm{C}$ for 4 weeks and the CIE $L^{*}, a^{*}$ and $b^{*}$ values were measured on a chromameter.

${ }^{2)}$ Group abbreviations: $\mathrm{N}$ represents nitrites in ppm, and A represents $A$ hookeri in $\%$ added in the process of preparation of sausages.

${ }^{a+}$ Means sharing a common superscript letter(s) in a column are not significantly different $(\mathrm{p}>0.05)$.

${ }^{A-D}$ Means sharing a common superscript letter(s) in a row are not significantly different $(\mathrm{p}>0.05)$.

\section{아질산염 잔유량}

삼채 분말과 아질산염 첨가량을 달리 하여 제조한 돈육 소시지를 $4^{\circ} \mathrm{C}$ 에서 4 주 동안 저장하면서 아질산염 잔유량을 측정한 결과 Table 7과 같다. 소시지 제조 후 아질산염 잔유 량은 $50 \mathrm{ppm}$ 첨가 시 $22.68 \pm 0.50 \mathrm{ppm}, 100 \mathrm{ppm}$ 첨가시 $47.49 \pm 2.05 \mathrm{ppm}, 150 \mathrm{ppm}$ 첨가 시 $65.63 \pm 2.01 \mathrm{ppm}$ 의 값을 보여 소시지 제조 중에 이미 첨가량의 절반 이상이 소거되 었음을 알 수 있었다. 저장 중 아질산염 잔유량의 변화를 살펴보면 저장 1 주 까지는 비교적 큰 폭의 잔유량 감소를 볼 수 있었으나 그 이후에는 변화 폭이 크지 않았다. 육가공 
품의 아질산염 함량은 제조 후 저장 기간이 질어짐에 따라 잔존 아질산염이 감소하며, 특히 제조 1 주일 이내에 그 감소 폭이 매우 큰 것으로 보고된바 있어 본 결과와 유사하다 $(37,38)$. 저장기간 동안 아질산염 잔유량의 감소는 아질산 염이 myoglobin, 지방 및 non-haemoprotein 등과 반응하는 데 기인하는 것으로 일부 설명된다(39). 저장 1 주 후에 더 이상 아질산염 잔유량이 변화되지 않은 결과는 기존의 보고 와는 다소 다른 결과로서, Choi 등(37)에 의하면 소시지를 $4^{\circ} \mathrm{C}$ 와 $20^{\circ} \mathrm{C}$ 에 각각 저장하였을 때 $4^{\circ} \mathrm{C}$ 에서는 5 주, $20^{\circ} \mathrm{C}$ 에서 는 2 주 저장 기간 동안 아질산염 잔유량이 계속 감소되었다. 삼채분말 첨가에 의한 아질산염 잔유량의 변화를 살펴보 면, 삼채 첨가에 의해 잔유량이 대체로 감소하는 경향이었 으나 감소폭은 크지 않았다.

Table 7. Residual nitrite contents of pork sausages prepared by addition of nitrite and $A$ hookeri during storage at $4^{\circ} \mathrm{C}$ for 4 weeks $^{1)}$

\begin{tabular}{ccccc}
\hline & \multicolumn{4}{c}{ Nitrite contents (ppm) } \\
\cline { 2 - 5 } & 0 week & 1 week & 2 week & 4 week \\
\hline $\mathrm{N} 0+\mathrm{A} 0^{2)}$ & $0.43 \pm 0.80^{\mathrm{g}}$ & $-0.15 \pm 0.12^{\mathrm{g}}$ & $-0.12 \pm 0.14^{\mathrm{e}}$ & $-0.15 \pm 0.12^{\mathrm{f}}$ \\
$\mathrm{N} 50+\mathrm{A} 0$ & $22.68 \pm 0.50^{\mathrm{dA}}$ & $16.60 \pm 0.81^{\mathrm{dB}}$ & $16.77 \pm 0.34^{\mathrm{cB}}$ & $17.09 \pm 0.19^{\mathrm{cB}}$ \\
$\mathrm{N} 50+\mathrm{A} 0.5$ & $20.08 \pm 0.40^{\mathrm{eA}}$ & $14.59 \pm 0.27^{\mathrm{eD}}$ & $17.14 \pm 0.64^{\mathrm{CB}}$ & $15.70 \pm 0.31^{\mathrm{dC}}$ \\
$\mathrm{N} 50+\mathrm{A} 1.0$ & $17.79 \pm 0.76^{\mathrm{fA}}$ & $13.70 \pm 0.59^{\mathrm{BB}}$ & $14.15 \pm 0.62^{\mathrm{dB}}$ & $14.30 \pm 0.30^{\mathrm{eB}}$ \\
$\mathrm{N} 100+\mathrm{A} 0$ & $47.49 \pm 2.05^{\mathrm{bA}}$ & $38.97 \pm 0.75^{\mathrm{bB}}$ & $40.75 \pm 2.06^{\mathrm{bB}}$ & $36.68 \pm 0.52^{\mathrm{bC}}$ \\
$\mathrm{N} 100+\mathrm{A} 0.5$ & $46.29 \pm 0.89^{\mathrm{bA}}$ & $36.07 \pm 0.62^{\mathrm{CC}}$ & $40.01 \pm 0.49^{\mathrm{bB}}$ & $36.64 \pm 0.66^{\mathrm{bC}}$ \\
$\mathrm{N} 100+\mathrm{A} 1.0$ & $44.89 \pm 0.83^{\mathrm{cA}}$ & $36.61 \pm 0.43^{\mathrm{cC}}$ & $40.13 \pm 1.25^{\mathrm{bB}}$ & $37.36 \pm 0.81^{\mathrm{bC}}$ \\
$\mathrm{N} 150+\mathrm{A} 0$ & $65.63 \pm 2.01^{\mathrm{aA}}$ & $57.47 \pm 0.79^{\mathrm{aC}}$ & $60.67 \pm 1.89^{\mathrm{aB}}$ & $57.47 \pm 1.16^{\mathrm{aC}}$ \\
\hline
\end{tabular}

${ }^{1)}$ Sausages prepared with addition of sodium nitrite $(0,50,100$, and $150 \mathrm{ppm})$ and $A$ hookeri powder $(0,0.5$, and $1.0 \%)$ were stored at $4{ }^{\circ} \mathrm{C}$ for 4 weeks and the residual nitrite contents were measured in ppm.

${ }^{2)}$ Group abbreviations: $\mathrm{N}$ represents nitrites in ppm, and A represents $A$ hookeri in $\%$ added in the process of preparation of sausages.

${ }^{a-g}$ Means sharing a common superscript letter(s) in a column are not significantly different $(p>0.05)$.

${ }^{A-D}$ Means sharing a common superscript letter(s) in a row are not significantly different ( $>0.05$ ).

\section{TBARS}

아질산염과 삼채 분말을 첨가하여 제조한 돈육 소시지를 $4{ }^{\circ} \mathrm{C}$ 에서 4 주 동안 저장하면서 thiobarbituric acid reactive substances(TBARS) 함량을 측정하여 지방의 산패를 살펴 본 결과(Table 8), 저장 기간이 길어질수록 TBARS 함량이 증가하였으나, 아질산염과 삼채 첨가량이 많을수록 증가폭 은 감소하였다. 아질산염의 항산화 기능과 그 기전에 대해 서는 다양한 연구결과가 보고되었다(40-44). Fleybler 등 (41)은 그들의 염지돈육 연구에서 아질산염이 불포화지방 과 니트로화합물을 생성하여 불포화지방을 안정화시킴으 로써 불포화지방의 과산화를 방지하는 것으로 항산화기전 을 설명하였다. 반면에 다른 여러 연구에서는 아질산염이 헴색소(heme pigments)와 복합체를 이루어 비헴철(non- heme iron)이 헴으로부터 이탈되는 것을 방지하거나, 아질 산염으로부터 생성된 nitric oxide(NO)가 비헴철 $\left(\mathrm{Fe}^{2+}\right)$ 에 직 접 작용함으로써 지방산화의 촉매로서 작용하지 못하도록 한다고 설명하였다(42-44).

삼채 첨가가 함량에 미치는 영향을 살펴보면, 아질산염 $100 \mathrm{ppm}$ 과 함께 삼채 $1 \%$ 첨가군(N100+A1.0)은 삼채 첨가 없이 아질산염만 $150 \mathrm{ppm}$ 첨가된 군(N150+A0)에 비해 제 조 직후에는 다소 높은 TBARS 값을 보였으나 저장기간이 길어질수록 N150+A0에 비해 낮은 값을 보여 항산화 기능 에 있어서 삼채의 아질산염 대체효과를 볼 수 있었다. 삼채 의 이러한 항산화작용은 활성산소에 의한 불포화지방산의 과산화 반응의 억제에 의한 것으로 생각되며, 그 주된 요인 중의 하나는 삼채의 함 유황 성분들이 관여하는 것으로 추정된다(45). 파, 마늘, 양파 등 유황을 함유하는 채소는 우리나라 전통 음식인 김치의 중요한 양념채소로 쓰이고 있으며, 유황 함유 화합물은 생체의 대사 과정 중 산화, 환원에 깊이 관여하여 radical에 의한 세포 손상에 대한 방어 기능을 수행한다(20). Banerjee와 Maulik(46)의 보고에 의하 면 마늘과 양파 추출물은 대사증후군을 가진 동물모델에 투여하였을 때, 산화 스트레스와 내피세포 염증인자의 발 현을 감소시키고 $\mathrm{eNOS}$ 활성을 증가시켜 항산화 및 항 염증 효과를 보였다.

Table 8. TBARS contents of pork sausages prepared by addition of nitrite and $A$ hookeri during storage at $4^{\circ} \mathrm{C}$ for 4 weeks ${ }^{1)}$

\begin{tabular}{ccccc}
\hline & \multicolumn{4}{c}{ TBARS contents (nmoles/g) } \\
\cline { 2 - 5 } & 0 week & 1 week & 2 week & 4 week \\
\hline $\mathrm{N} 0+\mathrm{A} 0^{2)}$ & $27.79 \pm 1.66^{\mathrm{aD}}$ & $56.03 \pm 2.46^{\mathrm{aC}}$ & $61.45 \pm 2.50^{\mathrm{aB}}$ & $95.40 \pm 1.49^{\mathrm{aA}}$ \\
$\mathrm{N} 50+\mathrm{A} 0$ & $10.32 \pm 0.49^{\mathrm{bC}}$ & $37.90 \pm 1.21^{\mathrm{bB}}$ & $37.67 \pm 1.05^{\mathrm{bB}}$ & $51.61 \pm 2.13^{\mathrm{bA}}$ \\
$\mathrm{N} 50+\mathrm{A} 0.5$ & $8.52 \pm 0.30^{\mathrm{cD}}$ & $29.05 \pm 2.59^{\mathrm{cC}}$ & $26.20 \pm 1.45^{\mathrm{cB}}$ & $38.43 \pm 1.86^{\mathrm{cA}}$ \\
$\mathrm{N} 50+\mathrm{A} 1.0$ & $7.06 \pm 0.70^{\mathrm{dD}}$ & $20.62 \pm 1.54^{\mathrm{dB}}$ & $18.06 \pm 1.63^{\mathrm{dC}}$ & $32.78 \pm 1.44^{\mathrm{dA}}$ \\
$\mathrm{N} 100+\mathrm{A} 0$ & $3.15 \pm 0.48^{\mathrm{fgD}}$ & $9.66 \pm 0.92^{\mathrm{eCC}}$ & $10.93 \pm 0.39^{\mathrm{eB}}$ & $23.15 \pm 0.67^{\mathrm{eA}}$ \\
$\mathrm{N} 100+\mathrm{A} 0.5$ & $4.01 \pm 0.53^{\mathrm{eCC}}$ & $10.73 \pm 0.19^{\mathrm{eB}}$ & $10.86 \pm 0.76^{\mathrm{eB}}$ & $18.26 \pm 0.81^{\mathrm{fA}}$ \\
$\mathrm{N} 100+\mathrm{A} 1.0$ & $4.31 \pm 0.63^{\mathrm{eC}}$ & $8.53 \pm 1.42^{\mathrm{fgA}}$ & $6.14 \pm 0.65^{\mathrm{fB}}$ & $6.56 \pm 0.42^{\mathrm{hB}}$ \\
$\mathrm{N} 150+\mathrm{A} 0$ & $2.74 \pm 0.24^{\mathrm{gD}}$ & $7.71 \pm 0.35^{\mathrm{gC}}$ & $9.86 \pm 0.59^{\mathrm{eB}}$ & $14.13 \pm 0.30^{\mathrm{gA}}$ \\
\hline
\end{tabular}

${ }^{1}$ Sausages prepared with addition of sodium nitrite $(0,50,100$, and $150 \mathrm{ppm})$ and $A$ hookeri powder $(0,0.5$, and $1.0 \%)$ were stored at $4^{\circ} \mathrm{C}$ for 4 weeks and the TBARS contents (nmoles/g) were measured.

${ }^{2)}$ Group abbreviations: N represents nitrites in ppm, and A represents $A$ hookeri in $\%$ added in the process of preparation of sausages.

${ }^{a-h}$ Means sharing a common superscript letter(s) in a column are not significantly different $(p>0.05)$.

A-D Means sharing a common superscript letter(s) in a row are not significantly different $(\mathrm{p}>0.05)$.

\section{일반세균}

돈육 소시지를 $4^{\circ} \mathrm{C}$ 에서 1 주와 4 주 동안 저장하여 총세균 수를 측정한 결과를 Table 9에 나타내었다. 아질산염과 삼 채를 첨가하지 않은 돈육 소시지(N0+A0)에서 가장 높은 일반 세균이 관찰되었으며, 저장 1 주차에서는 아질산염 50 
$\mathrm{ppm}$ 과 삼채 $1 \%$ 첨가군(N50+A1.0)이 아질산염 $100 \mathrm{ppm}$ 첨가군 $(\mathrm{N} 100+\mathrm{A} 0)$ 과 유의한 차이를 보이지 않았다. 또한 아질산염 $100 \mathrm{ppm}$ 과 삼채 $1 \%$ 첨가군(N100+A1.0)은 아질 산염 $150 \mathrm{ppm}$ 첨가군 $(\mathrm{N} 150+\mathrm{A} 0)$ 과 유의한 차이가 없었다. 4주 동안 저장한 제품에서는 아질산염 $50 \mathrm{ppm}$ 과 삼채 $1 \%$ 첨가군(N50+A1.0)이 아질산염 $100 \mathrm{ppm}$ 첨가군(N100+A0) 보다 총 균수가 적었으며 아질산염 $100 \mathrm{ppm}$ 과 삼채 $1 \%$ 첨가군 $(\mathrm{N} 100+\mathrm{A} 1.0)$ 은 아질산염 $150 \mathrm{ppm}$ 을 첨가한 군 $(\mathrm{N} 150+\mathrm{A} 0)$ 과 유의적인 차이가 없었다. 이러한 결과는 삼채 가 항균활성 기능에 있어서 일부 아질산염을 효과적으로 대체할 수 있음을 나타내고 있다. Sallam 등(47)은 계육 소 시지를 21 일 동안 저장하면서 미생물수를 측정한 결과 마 늘 분말 첨가구에서 대조구와 $\mathrm{BHA}$ 처리구보다 좋다고 하여 마늘의 우수한 항 미생물 기능을 보고하였고, FernandezLopez 등(48)과 Gorinstein 등(49)도 마늘의 미생물 성장 억 제 효과를 보고하여 본 실험 결과와 유사하였다.

이상의 결과를 종합하면 소시지 제조 시 삼채 분말 첨가 는 제품의 일반성분, 밝기, 적색도, 황색도 등 색깔과 조직감 및 아질산염 잔유량에 다소 영향을 미치나 영향이 크지 않고, 저장 중 TBARS 증가를 억제하며 일반세균수의 증가 를 억제하는 결과를 보였다. 삼채 첨가에 의한 TBARS와 세균증식 억제로 살펴볼 때 삼채를 $1 \%$ 첨가함으로써 아질 산염 사용량을 $150 \mathrm{ppm}$ 에서 $100 \mathrm{ppm}$ 으로 낮추어 아질산염 대체효과를 얻을 수 있는 가능성을 시사하였다. 이들 결과 는 삼채의 우수한 건강기능성을 활용한 고부가가치 육가공 품 개발을 위한 유용한 기초자료가 될 것이다.

Table 9. Microbial growth of pork sausage prepared by addition of nitrite and $A$ hookeri during storage at $4^{\circ} \mathrm{C}$ for 4 weeks $^{1)}$

\begin{tabular}{ccc}
\hline & \multicolumn{2}{c}{ Total plate counts (CFU/g) } \\
\cline { 2 - 3 } & 1 week & 4 week \\
\hline $\mathrm{N} 0+\mathrm{A} 0^{2)}$ & $200.4 \pm 18.72^{\mathrm{a}}$ & $8,180.0 \pm 570.1^{\mathrm{a}^{*}}$ \\
$\mathrm{~N} 50+\mathrm{A} 0$ & $126.8 \pm 13.44^{\mathrm{b}}$ & $746.4 \pm 219.9^{\mathrm{b}^{*}}$ \\
$\mathrm{~N} 50+\mathrm{A} 1.0$ & $92.8 \pm 8.22^{\mathrm{c}}$ & $290.0 \pm 111.4^{\mathrm{c}^{*}}$ \\
$\mathrm{~N} 100+\mathrm{A} 0$ & $86.0 \pm 12.48^{\mathrm{c}}$ & $836.0 \pm 466.4^{\mathrm{b}^{*}}$ \\
$\mathrm{~N} 100+\mathrm{A} 1.0$ & $11.8 \pm 1.96^{\mathrm{d}}$ & $68.0 \pm 18.2^{\mathrm{c}^{\star}}$ \\
$\mathrm{N} 150+\mathrm{A} 0$ & $2.6 \pm 1.47^{\mathrm{d}}$ & $30.0 \pm 12.6^{6^{\star}}$ \\
\hline
\end{tabular}

${ }^{1)}$ Sausages prepared with addition of sodium nitrite $(0,50,100$, and $150 \mathrm{ppm})$ and $A$ hookeri powder ( 0 and 1.0\%) were stored at $4^{\circ} \mathrm{C}$ for 4 weeks and the total plate counts were measured in $\mathrm{CFU} / \mathrm{g}$.

${ }^{2}$ Group abbreviations: $\mathrm{N}$ represents nitrites in ppm, and A represents $A$ hookeri in $\%$ added in the process of preparation of sausages.

${ }^{a-d}$ Means sharing a common superscript letter(s) in a column are not significantly different $(p>0.05)$.

"Significantly different from 1 week $(p<0.05)$.

\section{요 약}

삼채의 다양한 기능성을 육가공품에 활용하기 위한 기초
자료를 얻기 위하여 이의 첨가가 돈육 소시지의 물리 화학 적 특성과 저장성에 미치는 영향을 살펴보았다. 삼채 분말 $0,0.5,1 \%$ 와 아질산염 $0,50,100,150 \mathrm{ppm}$ 을 첨가하여 제조한 소시지의 색깔을 측정한 결과 제품의 밝기 (lightness)는 아질산염 첨가에 의해 감소하였으나, 삼채 첨 가에 의해서는 크게 영향을 받지 않았다. 적색도(redness)는 아질산염 첨가에 의해 현저히 증가하고 삼채 첨가에 의해 다소 감소하는 경향을 보였으며, 저장 중 변화는 처리군에 따라 차이가 있었다. 황색도(yellowness)는 아질산염 첨가 군이 무첨가군에 비해 낮은 값을 보였으나 삼채 첨가는 황색도를 다소 증가시켰다. 소시지의 경도(hardness)와 씹 힘성(chewyness)은 군 간에 유의적 차이가 있었으나, 아질 산염과 삼채의 첨가에 따른 뚜렷한 경향은 발견되지 않았 다. 아질산염은 소시지 제조 중에 이미 첨가량의 절반 이상 소거되었으며, 저장 1 주 까지 비교적 큰 폭의 감소를 볼 수 있었으나 그 이후에는 변화가 적었다. 아질산염 잔유량 은 삼채 첨가에 의해 다소 감소하는 경향이었으나 감소폭은 크지 않았다. TBARS 함량을 측정하여 지방의 산화를 살펴 본 결과, TBARS 함량은 저장 기간이 길어질수록 증가하였 으나, 아질산염과 삼채 첨가량이 많을수록 증가폭이 감소 하였다. 2주 이상 저장할 경우 아질산염 $100 \mathrm{ppm}$ 과 함께 삼채 $1 \%$ 첨가군은 삼채 첨가 없이 아질산염만 $150 \mathrm{ppm}$ 첨가된 군에 비해 낮은 $\mathrm{TBARS}$ 값을 보였다. 제품을 $4^{\circ} \mathrm{C}$ 에 서 4주 동안 저장 하면서 일반세균을 측정한 결과, 아질산염 $50 \mathrm{ppm}$ 과 함께 삼채를 $1 \%$ 첨가한 군이 아질산염만 100 $\mathrm{ppm}$ 첨가한 군에 비해 총 균수가 적었으며, 아질산염 100 $\mathrm{ppm}$ 과 함께 삼채를 $1 \%$ 첨가한 군은 아질산염만 $150 \mathrm{ppm}$ 을 첨가한 군과 유의적인 차이가 없었다. 이상의 결과는 소시 지 제조 시 삼채 분말 첨가는 저장 중 TBARS 증가를 억제시 키고 미생물의 증식 억제시킴으로써 제품의 저장성에 있어 서 일부 아질산염 대체효과를 얻을 수 있는 가능성을 시사 한다.

\section{References}

1. Park SM, Youn SK, Kim, HJ, Ahn DH (1999) Studies on the improvement of storage property in meat sausage using chitosan. J Korea Soc Food Sci Nutr, 28, 167-171

2. Gray JI, MacDonald B, Pearson AM, Morton ID (1981) Role of nitrite in cured meat flavor: a review. J Food Prot, 44, 302-312

3. Cassens RG (1997) Residual nitrite in cured meat. Food Technol, 51, 53-55

4. Mirvish SS, Reimers KJ, Kutler B, Chen SC, Haorah J, Morris CR, Grandjean AC, Lyden ER (2000) Nitrate and nitrite concentrations in human saliva for men and 
women at different ages and times of the day and their consistency over time. Eur J Cancer Prev, 9, 335-342

5. Chow CK, Hong CB (2002) Dietary vitamin E and selenium and toxicity of nitrite and nitrate. Toxicology, 180, 195-207

6. Bloukas JG, Arvanitoyannis IS, Siopi AA (1999) Effect of natural colourants and nitrites on colour attributes of frankfurters. Meat Sci, 52, 257-265

7. Kim HK, Na GM, Ye SH, Han HS (2004) Extraction characteristics and antioxidative activity of Lycium chinense extracts. Korean J Food Preserv, 11, 352-357

8. Na GM, Han HS, Ye SH, Kim HK (2004) Extraction characteristics and antioxidative activity of Cassia tora L. extracts. Korean J Food Culture, 19, 499-505

9. Namsa ND, Mandal1 M, Tangjang S, Mandal SC (2011) Ethnobotany of the Monpa ethnic group at Arunachal Pradesh, India. J Ethnobiol Ethnomed, 7, 31-44

10. Ayam VS (2011) Allium Hookeri, Thw. Enum. A lesser known terrestrial perennial herb used as food and its ethnobotanical relevance in Manipur. Afr J Food Agric Nutr Dev, 11, 5389-5412

11. Swarnalata N, Sharma S (2016) Physicochemical evaluation for Allium Hookeri Thw. Enum leaves. Int J Phytomed, 8, 319-324

12. Rhyu DY, Park SH (2013) Characterization of alkyl thiosulfinate in Allium hookeri root using HPLC-ESI-MS. J Korean Soc Appl Biol Chem, 56, 457-459

13. Wahengbam OD, Patel D (2014) Effect of drying technique on nutritional and phytochemical of Allium hookeri thwaites (leaves and roots). Int J Adv Res Tech, 3, 1-7

14. Kim KH, Kim HJ, Byun MW, Yook HS (2012) Antioxidant and antimicrobial activities of ethanol extract from six vegetables containing different sulfur compounds. J Korean Soc Food Sci Nutr, 41, 577-583

15. Cho HS, Park W, Hong GE, Kim JH, Ju MG, Lee CH (2015) Antioxidant activity of Allium hookeri root extract and its effect on lipid stability of sulfur-fed pork patties. Korean J Food Sci Anim Resour, 35, 41-49

16. Lee Y, Lee SH, Lee SJ, Gadde UD, Oh ST, Han H, Lillehoj HS (2018) Effects of dietary Allium hookeri root on growth performance and antioxidant activity in young broiler chickens. Res Vet Sci, 118, 345-350

17. Roh SS, Kwon OJ, Yang JH, Kim YS, Lee SH, Jin JS, Jeon YD, Yokozawa T, Kim HJ (2016) Allium hookeri root protects oxidative stress-induced inflammatory responses and $\beta$-cell damage in pancreas of streptozotocin-induced diabetic rats. BMC Complementary Altern Med, 16, 63-72

18. Nam GH, Lee SJ, Kim GY, Jeon MJ, Jo KJ, Park YS, Kim SY, Kim YM (2018) The Extracts from Allium hookeri induces p53-independent apoptosis through mitochondrial intrinsic pathways in AGS human gastric carcinoma cells. J Cancer Sci Ther, 10, 198-204

19. Bae GC, Bae DY (2012) The anti-inflammatory effects of ethanol extract of Allium Hookeri cultivated in South Korea. Korean J Herbol, 27, 55-61

20. Kim CH, Lee MA, Kim TW, Jang JY, and Kim HJ (2012) Anti-inflammatory effect of Allium hookeri root methanol extract in LPS-induced RAW264.7 cells. J Korean Soc Food Sci Nutr, 41, 1645-1648

21. Jang JY, Min-Jung Lee, You BR, Jin JS, Lee SH, Yun YR, Kim HJ (2017) Allium hookeri root extract exerts antiinflammatory effects by nuclear factor- $\kappa \mathrm{B}$ downregulation in lipopolysaccharide-induced RAW264.7 cells. BMC Complementary Altern Med, 17, 126-134

22. Kim JE, Park KM, Lee SY, Seo JH, Yoon IS, Bae CS, Yoo JC, Bang MA, Cho SS, Park DH (2017) Anti-inflammatory effect of Allium hookeri on carrageenan-induced air pouch mouse model. PLoS ONE, $12,1-11$

23. Lee HA, Hong S, Yoo JH, Chung Y, Kim O (2018) Anti-Helicobacter pylori activity and inhibition of gastritis by Allium hookeri extract. Lab Anim Res, 34, 75-79

24. Kang HY, Lee CE, Ly SY (2016) Protective effects of ethanol extract of Allium hookeri root on acute alcohol-induced intoxication in ICR Mice. J Korean Soc Food Sci Nutr, 45, 625-633

25. Yang MH, Kim NH, Heo JD, Rho JR, Ock KJ, Shin EC, Jeong EJ (2017) Comparative evaluation of sulfur compounds contents and antiobesity properties of Allium hookeri prepared by different drying methods. Evidence-Based Com Alt Med, 2017, 1-10

26. Lee N, Lee RM, Lee CH (2017) Effects of dietary Allium hookeri root powder on the body fat deposition and biochemical parameters in guinea pigs. J Anim Res Nutr, 2, 16-21

27. Lee SH, Kim NS, Choi BK, Jang HH, Kim JB, Lee YM, Kim DK, Lee CH, Kim YS, Yang JH, Kim YS, Kim HJ, Lee SH (2015) Effects of Allium hookeri on lipid metabolism in type II diabetic mice. Kor J Pharmacogn, 46, 148-153

28. Kim NS, Choi BK, Lee SH, Jang HH, Kim JB, Kim 
HR, Kim DK, Kim YS, Yang JH, Kim HJ, Lee SH (2015) Effects of Allium Hookeri on glucose metabolism in type II diabetic mice. Kor J Pharmacogn 46, 78-83

29. Won JY, Yoo YC, Kang EJ, Yang H, Kim GH, Seong BJ, Kim SI, Han SH, Lee SS, Lee KS (2013) Chemical components, DPPH radical scavenging activity and inhibitory effects on nitric oxide production in Allium hookeri cultivated under open field and greenhouse conditions. J Korean Soc Food Sci Nutr, 42, 1351-1356

30. You BR, Kim HJ (2013) Quality characteristics of Kimchi added with Allium hookeri root. J Korean Soc Food Sci Nutr, 42, 1649-1655

31. Park MY, SY Ly (2015) Quality characteristics of seasoned pork with water extracts of Allium hookeri root during storage. J Korean Soc Food Sci Nutr, 44, 242-249

32. AOAC (1990) Official Method of Analysis. $15^{\text {th }}$ ed, Association of Official Analytical Chemists, Washington DC, USA, p 931-937

33. Witte VC, Krause GF, Baile ME (1970) A new extraction method for determining 2-thiobarbituric acid values of pork and beef during storage. J Food Sci, 35, 352-358

34. Kim SM, Cho YS, Sung SK, Lee IG, Lee SH, Kim DG (2002) Developments of functional sausage using plant extracts from pine needle and green tea. Korean J Food Sci Ani Resour, 22, 20-29

35. Hong G, Lee S, Min SG (2003) Studies on physico-chemical properties of spreadable liver sausage during storage period. Korean J Food Sci Ani Resour, 23, 56-62

36. Wesley RL, Marion WW, Sebranek JG (1982) Effect of sodium nitrite concentration, sodium erythorbate and storage time on the quality of franks manufactured from mechanically deboned turkey. J Food Sci, 47, 1626-1630

37. Choi SH, Kwon HC, An DJ, Park JR, Oh DH (2003) Nitrite contents and storage properties of sausage added with green tea powder. Korean J Food Sci Ani Resour, 23, 299-308

38. Hustad GO, Cerveny JG, Trenk H, Deibel RH, Kautter DA, Fazio T, Johnston RW, Kolari OE (1973) Effect of sodium nitrite and sodium nitrate on botulinal toxin production and nitrosamine formation in wieners. Appl Microbiol, 26, 22-26
39. Sammet K, Duehlmeier R, Sallmann HP, von Canstein C, von Mueffling T, Nowak B (2006) Assessment of the antioxidative potential of dietary supplementation with a-tocopherol in low-nitrite salami-type sausage. Meat Sci, 72, 270-279

40. Zubillaga MP, Maerker G, Foglia TA (1984) Antioxidant activity of sodium nitrite in meat. JAOCS, 61, $772-776$

41. Fleybler LA, Gray JI, Asghar A, Boreen AM, Pearson AM, Buckley DJ (1993) Nitrite stabilization of lipids in cured pork. Meat Sci, 33, 85-96

42. Igene JO, Yamauchi K, Pearson AM, Gray JI, Aust SD (1985) Mechanisms by which nitrite inhibits the development of warmed-over flavour (WOF) in cured meat. Food Chem, 18, 1-18

43. Morrissey PA, Tichivangana JZ (1985) The antioxidant activities of nitrite and nitrosylmyoglobin in cooked meats. Meat Sci, 14, 175-190

44. Kanner J, Harel S, Shagalovich J, Berman S (1984) Antioxidative effect of nitrite in cured meat products: nitric oxide-iron complexes of low molecular weight. J Agric Food Chem, 32, 512-515

45. Hsu CC, Huang CN, Hung YC, Yin MC (2004) Five cysteine-containing compounds have antioxidative activity in Balb/cA mice. J Nutr, 134, 149-152

46. Banerjee SK, Maulik SK (2002) Effect of garlic on cardiovascular disorders: a review. Nutr J, 1, 1-14

47. Sallam KhI, Ishioroshi M, Samejima K (2004) Antioxidant and antimicrobial effects of garlic in chicken sausage. LWT-Food Sci Technol, 37, 849-855

48. Fernandez-Lopez J, Zhi N, Aleson-Carbonell L, Perez-Alvarez JA, Kuri V (2005) Antioxidant and antibacterial activities of natural extracts: application in beef meatballs. Meat Sci, 69, 371-380

49. Gorinstein S, Drzewieki J, Leontowicz H, Leontowicz M, Najman K, Jastrzebski, Z (2005) Comparison of the bioactive compounds and antioxidant potentials of fresh and cooked Polish, Ukrainian, and Israeli garlic. J Agri Food Chem, 53, 2726-2732 